water, the time of their occurrence, and the range of the tide for every day of the same month as before. Table III. is similar to Table I., but the hours are counted each day from the upper culmination of the moon, instead of from noon. By thus arranging the table, the sun's influence is eliminated in the means for each hour, and the moon's influence on the tide is thus made apparent. Table V. corresponds to Table IV. The remaining tables, VI. to XII., give information as regards the interval of time between the moon's upper or lower culmination and high water, and similarly for low water; also the height of the highest and lowest high and low water recorded each month, specifying the direction of the wind and the height of the barometer; and lastly, the greatest and least range of the tide during each month.

The report concludes with a comparison of the semimenstrual inequality as calculated by Whewell's formulæ, and the actual observed inequalities. The agreement is very close.

There is no discussion in the report of the results obtained, this being reserved for future publications, when the observations at the other stations are available.

The report is accompanied by five plates, showing the registering apparatus, and giving specimens of the diagrams.

\section{SCIENTIFIC HERESIES IN CHINA}

THE belief of the old writer who explained the disappearance of the swallows in autumn, by the assumption that they all rolled themselves together into a mass, beak to beak and wing to wing, and plunged "fluminibus lacubusque," there to remain until the return of spring, is but an instance of the thousand and one theories which have from all time been held by unscientific observers on the subject of the annual appearance and disappearance of migrating birds. It is not so very long ago that even among ourselves the question of the migration of sand martens was a moot point; and it need not be a matter of surprise, therefore, that the Chinese, though keen observers of nature, should be guilty of holding heretical hypotheses to account for the presence in summer and the absence in winter of birds of passage, as well as for other processes of nature which are enacted before them. Like most common fallacies, those current in China on these subjects are derived from ancient authorities, but, unfortunately, in the case of the Chinese, whose respect for everything that is old is supreme, this antiquity only entails upon them the more unquestioning faith. They are, therefore, perfectly content to believe that the disappearance of quails in autumn is sufficiently accounted for by the assumption that at that time of the year they are transformed into moles, and that in spring they succeed in reappearing again in beaks and feathers. The explanation of this fallacy is simple enough. The ploughman who in the spring and summer has seen the quails flitting among the mole-hills, finds that when, the birds having disappeared, he ploughs over the same land in winter, the moles, which he has not before seen, are the sole occupants of the ground.

Another generally accepted belief is based on what Max Muiller calls a disease of language. At the opening of spring, bawks are said to become pigeons, and at midsummer to be reconverted to their original shapes. Now it happens that $K i u$, the Chinese name for a pigeon, forms the second syllable of the word for a crested hawk (Shwang-kiu), and it would appear that by a corruption of terms and a confusion of ideas the first syllable has been dropped and the last has been allowed to stand in its literal and isolated meaning. Thus the original assertion that during the breeding season hawks become crested has been perverted into a meaningless and self-condemnatory myth. Chinese writers on natural history lay stress on the fact that during the spring, when "the rearing instinct in birds becomes excessive, birds of prey become excited," and when excited or angry, hawks, as is well known, erect the feathers on the head, giving the appearance of a crest.

Much in the same way has arisen the legend that in late autumn certain small birds go into the sea and become crustacer. In this case the error depends on the word wei, which is here translated "become," but which also means "for," and which, when so read, converts an absurdity into the record of a fact concerning the birds probably referred to, namely, sandpipers. These birds, we know, "frequent sandy sea-shores, some of them congregating in numerous flocks in autumn and winter, and seek their food by probing the sand with their bills, and by catching small crustaceans in pools or within the margin of the sea itself." 1 The same mistake, which is, however, complicated by a further misunderstanding, makes it incumbent on Chinamen to believe that in winter pheasants go into the lakes and become clams. The word here translated "clams" means also "sweet flags and water rushes," and in search of these hungry pheasants might very probably be tempted to seek the margins of swamps and lakes. A curious and unaccountable superstition was anciently and is still connected with this habit of Chinese pheasants. We have it on the authority of one of the Classics that " if within ten days from the beginning of winter pheasants do not go to the great waters, lascivious women will multiply in the country."

Otters and polecats, again, are the subjects of a more sentimental belief. They are said to be in the habit of offering up, the one fish, and the other animals, in sacrifice. This strange myth is accentuated in the "Imperial Encyclopædia," published by order of the Emperor K'ang-he (166I-1722), by an illustration attached to the chapter on otters, in which one of those animals is represented as squatting down on the bank of a river with his two forepaws on a newly-captured trout, and with a most devout expression on his upturned face, which is directed towards the moon. The explanation of this legend is not far to seek.

The habit common to both otters and polecats of destroying many more creatures than they are able to devour, and of leaving their victims apparently untouched after having satisfied their appetites with the flakes at the back of the fishes' necks, and with the blood of the animals, suggests to careless and superstitious observers the semblance of propitiatory sacrifices offered up to the patron saints of vermin.

Many other generally accepted myths might be quoted, which are but the perverted representations of facts. But if we descend to a lower level, to the vulgar superstitions of the masses, we find ourselves in a region where-

$$
\text { "Wisdom and Wit are little seen, }
$$

A resemblance in outward form, or even in disposition, is enough to give rise to a belief that the animals are interchangeable. Thus eels are said at times to be transformed into serpents, mice into bats, and sharks into tigers, and vice versâ. By a curious connection of ideas, between kings and whales, also comets, those stars so abhorred by rulers, are considered to be as destructive to the lives of the monarchs of the deep as of the sovereigns of the soil.

$$
\text { NOTES OF TRAVEL IN SARDINIA }
$$

WHILE Sicily possesses classical associations and remains of the highest interest, together with physical features more or less dependent upon the presence of the most famous volcano in the world; and while Lipari and the associated islands are remarkable for their evidences of past and present volcanic action,

$$
\text { ' Chambers' Encyclopadia. }
$$


Sardinia can lay claim to neither the one interest nor the other, to any marked degree. Neither can we compare it with Iceland, or with Majorca, and perhaps the only special interest which belongs to it is the occurrence of large numbers of nuraghi-conical stone mounds of prehistoric construction, hollow within, and probably designed as tombs by "the earliest inhabitants of the island. These are scattered over the island in large numbers, particularly near Torralba.

In Roman times Sardinia never rose to much importance, hence the relics of that period are but few. The most important is an amphitheatre near Cagliari hewn out of the rock, the major axis of which is 153 feet in length, and the minor axis 98 feet. It is now in a very dilapidated condition, far more so indeed than that of Puzzuoli. There are also a few Roman tombs. The most remarkable is in a suburb of Cagliari called Santa Tenera, and it is known as the Grutta dessa Pibera, that is the Grotto of the Viper, from the serpents which are sculptured over the entrance. It was the tomb of Attilia Pamphilla, a noble Roman lady. On the walls there are some interesting inscriptions, which have been published by General $\mathrm{La}$ Marmora and by Muratori.

The few travellers who visit Sardinia nowadays are tempted rather by prospects of sport than by anything else. Moufflons still exist among the Gennargentu Mountains, also wild boar, and smaller game, but the amount of sport afforded by the island has been exaggerated, and the sportsman will commonly prefer to go to the north of Norway or to Iceland to running the risk of catching malarious fever in Sardinia.

Malaria has always been very prevalent in the island. There is a large extent of marsh land, and in the autumn a great deal of decomposing vegetable matter. We were glad to notice that some of the Englishmen who have recently acquired land in the island have not only commenced draining operations, but have also planted numbers of Eucalyptus trees, the effect of both operations being undoubtedly to diminish malaria. On the other hand, many of the native landowners are converting their timber into charcoal, for which they can obtain about fifty francs a ton in France and elsewhere. Some thousands of tons are annually shipped, and unfortunately new trees are not planted in place of the old ones. If this wholesale destruction of forests continues, there can be no doubt that the climate of the country will eventually be seriously affected. The exporters do not in the least realise that they are shipping vis viva in a very condensed form from their shores, and at the same time diminishing the rainfall.

The chief wealth of Sardinia lies in her mines of argentiferous galena, and of calamine. As much as 120 ounces per ton of silver have been extracted from some of the lead ores. The principal mines are those of Monte Poni, near Iglesias, in the south-west of the island, and of Monte Vecchio, in the west centre. At Monte Poni we noticed that the newest forms of Belgian and German machinery for crushing and washing the ores were in use. At the present time, the operations are very much impeded by the flow of water into the principal shaft, which will probably be to a great extent obviated, by boring a tunnel through the side of the mountain in which the shaft is sunk.

A railway constructed, and to a great extent owned by an English company, now connects the two capital cities of the island-Cagliari and Sassari-a distance of 260 kilometres, with branches to Iglesias, in the south-west, and to Terranova in the north-east, and the line is continued from Sassari for $12 \frac{1}{2}$ miles to Portotorres, its port, a miserable and fever-stricken village. Fifty years ago, there were scarcely any roads at all in Sardinia. The Roman roads had become obliterated, and no attempt had been made to construct them afresh.

The railway is well constructed, but the trains are extremely slow, and do not average more than seventeen miles an hour. Between Macomer and Chilirani there are many cuttings and some very steep gradients. The railway connecting the two capitals-Cagliari and Sassari - has only recently been completed. Sassari, a town of 33,000 inhabitants, is nearly as large as Cagliari, and in some respects preferable to it. It stands upon a hill 650 feet above the sea. It has a clean, bright appearance, but in reality is very badly drained and extremely unhealthy. So recently as I 855 the cholera carried off nearly one-third of the population in less than three weeks, at the rate of more than 500 a day.

In Torralba there are a number of nuraghi, and in the neigh bourhood several extinct volcanoes, the most important of which is Keremule. Nearly midway between Mores and Torralba we saw exposed, in a recent railway cutting, a fine mass of columnar basalt overlying chalk. There is a good deal of pale green, pale pink, and grey trachite in the neighbourhood. The only geological map of the island which now exists is in General La Marmora's fine monograph published in Paris and Turin between 1839 and I860, and entitled Voyage en Sardaigne.

G. F. RODWELL

\section{MATHEMATICS IN SCANDINAVIA ${ }^{1}$}

THE first part of the new mathematical journal has reached us. We have not quite reproduced the title; the words Zeitschrift herausgegeben von on one side of the axis of symmetry (let us say) of the page, are matched by the words Fournal rédigé par on the other side. This is significant of one part of the Editor's plan: the journal, though printed and published in Stockholm, is to have its articles written in what the Editor styles the principal languages. It may be that English is one of these languages; there is not, however, in the preface, anything definite to relieve our doubts. The prospectus (unintentionally, we hope) is somewhat more informatory. In the language of our "lucid" neighbours it says: "In Germany, in France, in Italy, in Scandinavia, everywhere in fact, where science is held in honour (other side of the line of symmetry-'iiberall wo mathematisches Leben herrscht'), the idea of starting the journal was received with the most lively sympathy." Apparently in regard to the English language and English science, the less said the better. We, for our part, say nothing.

In outward appearance the new journal closely resembles Crelle's. The paper is equally good, the margin equally broad, and the size of page and the number of pages in a part substantially the same in the two serials. Neither is quite so handsome as a third member of the same family, the now five-year old American Fournal of Mathematics; but then we must not forget the ratio of five dollars to twelve marks.

The list of the editorial staff supporting M. MittagLeffler contains many distinguished names. There are five Swedish mathematicians, four Norwegians, three Danish, and one from Finland; and scarcely one of these but is well known far beyond his native country.

The contents of the first part are all that could be expected from such a brotherhood, headed by such a chief. The first paper is by Prof. Poincaré, of Paris, its subject being the Théorie des groupes fuchsiens. It extends to $62 \mathrm{pp}$., and is altogether worthy of its place of honour. One does not know which to admire most-the author's grasp of his subject, or the clearness and simplicity of his exposition. Following this, comes a contribution of 14 pp. by Prof. Malmsten, of Upsala, "Zur Theorie der Leibrenten;" then there is a paper of $16 \mathrm{pp}$. on "Eine Annäherungsmethode im Probleme der drei Körper," by M. Gylden, the head of the Stockholm Observatory; and lastly, to complete the 96 pages, there is

I Acta Mathematica: $Z$-itschrif herausgegeben, von G. Mittag-Leffler. (Stockholm, x882.) 